\title{
PERTUMBUHAN TEGAKAN KAYU BAWANG (Disoxylum mollissimum Bl.) PADA BERBAGAI POLA TANAM DAN KERAPATAN TEGAKAN
}

\author{
Growth of kayu bawang (Disoxylum mollissimum B1.) \\ at various planting pattern and stand density
Hengki Siahaan ${ }^{1}$, Endang Suhendang ${ }^{2}$, Teddy Rusolono ${ }^{2}$ dan/and Agus Sumadi ${ }^{1}$
${ }^{1)}$ Balai Penelitian Kehutanan Palembang
Jl. Kol. H. Burlian Km. 6,5 Kotak Pos 179, Puntikayu, Palembang Telp./Fax. 0711-414864
${ }^{2)}$ Departemen Manajemen Hutan, Institut Pertanian Bogor
Kampus IPB Darmaga, Jl. Raya Darmaga, Bogor \\ Naskah masuk : 7 Januari 2011; Naskah diterima : 5 September 2011
}

\begin{abstract}
Kayu bawang has been developed as farm forestry in Bengkulu Province, but until now, information concerning growth and yield for this species is not available, because the limited of quantification research on farm forestry. This reserch is aimed to construct growth model for kayu bawang at agroforestry planting pattern kayu bawang + kopi and multispecies agroforestry with various level of stand density. The result based on weighted least square (WLS) regression analisys is that growth model of kayu bawang for planting pattern agroforestry kayu bawang + coffee are $D=44,7101 A^{0,4481} N^{0,2843}, H=$ $30,4109 \mathrm{~A}^{0,3964} \mathrm{~N}^{0,2216}$, and $\operatorname{Ln} V=6,2236-6,8892 / \mathrm{A}-133,85 / \mathrm{N}$ respectively for diameter, height, and volume stand variabel. For planting pattern multispecies agroforestry, the models are Ln $D=2,6438$ $1,290 / \mathrm{A}+111,37 / \mathrm{N}, H=8,4351 \mathrm{~A}^{0,4882} \mathrm{~N}^{0,0399}$, and $\operatorname{Ln} V=4,0009-4,7611 / \mathrm{A}+0,21867 \ln \mathrm{N}$. These models show that kayu bawang stand growth at agroforestry planting pattern kayu bawang + kopi is better from that of multispecies agroforestry. For both planting pattern, the higher stand density, the higher stand volume per unit area, but diameter growth will decrease.
\end{abstract}

Keywords: Kayu Bawang (Disoxylum molliscimum Bl.), growth, planting pattern, stand density

\begin{abstract}
ABSTRAK
Kayu bawang telah dikembangkan dalam bentuk hutan rakyat di Provinsi Bengkulu, namun hingga saat ini, informasi mengenai pertumbuhan dan hasil jenis ini belum tersedia karena terbatasnya penelitian kuantifikasi pada hutan rakyat. Penelitian ini bertujuan untuk membangun model pertumbuhan kayu bawang pada pola tanam agroforestry kayu bawang + kopi dan agroforestry multi jenis dengan berbagai tingkat kerapatan. Hasil penelitian berdasarkan analisis regresi terboboti adalah bahwa model pertumbuhan kayu bawang untuk pola agroforestry kayu bawang + kopi adalah $\mathrm{D}=44,71013 \mathrm{~A}^{0,44807} \mathrm{~N}^{-}$ ${ }_{0,2843}, \mathrm{H}=30,41087 \mathrm{~A}^{0,39637} \mathrm{~N}^{-0,22306}$, dan $\mathrm{Ln} \mathrm{V}=6,2236-6,8892 / \mathrm{A}-133,85 / \mathrm{N}$, masing-masing untuk variabel diameter, tinggi, dan volume tegakan. Untuk pola agorforestry multijenis adalah $\mathrm{Ln} \mathrm{D}=2,64378$ - 1,290/A $+111,37 / \mathrm{N}, \mathrm{H}=8,4351 \mathrm{~A}^{0,48802} \mathrm{~N}^{-0,03989}$, dan $\mathrm{Ln} \mathrm{V}=4,0009-4,7611 / \mathrm{A}+0,21867 \ln \mathrm{N}$. Model-model ini menunjukkan bahwa pertumbuhan tegakan kayu bawang pada pola agroforestry kayu bawang + kopi lebih baik dibandingkan pola agroforestry multijenis. Model tersebut juga menunjukkan bahwa semakin tinggi kerapatan, maka volume tegakan per satuan luas akan semakin besar, tetapi pertumbuhan diameter akan menurun.
\end{abstract}

Kata kunci : Kayu Bawang (Disoxylum molliscimum Bl.), pertumbuhan, pola tanam, kerapatan tegakan 


\section{PENDAHULUAN}

Hutan rakyat merupakan salah satu bentuk hutan yang ditanam pada lahan milik masyarakat. Hutan rakyat kayu bawang (Disoxylum mollissimum B1.) merupakan salah satu contoh hutan rakyat yang cukup berkembang di Provinsi Bengkulu. Kayu bawang merupakan jenis lokal yang mempunyai pertumbuhan cepat (daur 10 - 15 tahun) dan kualitas kayu yang baik, terutama untuk kayu pertukangan. Kayu ini dapat tumbuh pada berbagai bentuk lahan, baik datar, miring maupun curam (kelerengan $>40 \%$ ), pada ketinggian $0-1000 \mathrm{~m} \mathrm{dpl}$, dengan curah hujan $500-3.500 \mathrm{~mm} / \mathrm{tahun}$ (Dinas Kehutanan, 2003).

Pengembangan kayu bawang dalam bentuk hutan rakyat dimulai pada tahun 1990-an. Teknologi budidaya yang dilakukan masih sederhana dengan input yang minimal. Pengaturan jarak tanam belum dilakukan sehingga petak penanaman yang dijumpai mempunyai kerapatan yang sangat beragam, yaitu berkisar antara $150-1250$ pohon/hektar. Penanaman dilakukan dengan pola tumpangsari atau pola agroforestry. Pada pola tumpangsari, kayu bawang ditanam dengan jenis tanaman semusim seperti cabe dan kacang tanah, namun pola ini tidak banyak dijumpai, sedangkan pola agroforestry dapat dijumpai dalam bentuk kombinasi antara kayu bawang dan kopi atau dalam bentuk kombinasi multi jenis dengan kopi, karet, dan kayu manis. Pada pola agroforestry kayu bawang dengan tanaman kopi, kayu bawang sekaligus berfungsi sebagai pelindung.

Upaya peningkatan produktivitas hutan rakyat memerlukan sistem pengelolaan yang baik dan terencana. Sistem pengelolaan yang baik membutuhkan berbagai perangkat pengelolaan seperti model penduga volume, model kualitas tempat tumbuh, dan model pertumbuhan dan hasil tegakan. Sumadi dan Siahaan (2010) telah menyusun model penduga volume kayu bawang berdasarkan satu variabel penduga diameter (D), yaitu $\mathrm{V}=0,000124 \mathrm{D}^{2,470}\left(\mathrm{R}^{2}=\right.$ 95,65\%). Model ini digunakan untuk menduga volume kayu bawang hingga diameter ujung $7 \mathrm{~cm}$. Model penduga volume bermanfaat untuk menduga potensi tegakan saat ini, sedangkan untuk menduga potensi tegakan yang dapat diperoleh pada masa yang akan datang diperlukan model pertumbuhan dan hasil.
Penelitian ini dilakukan untuk memenuhi salah satu perangkat pengelolaan hutan rakyat kayu bawang di Provinsi Bengkulu, yaitu model pertumbuhan tegakan. Model disusun dengan menggunakan variabel umur (A) dan kerapatan tegakan $(\mathrm{N})$ pada dua pola tanam kayu bawang yang banyak dijumpai di daerah tersebut, yaitu pola agroforestry kayu bawang + kopi dan agroforestry multijenis. Selain untuk me-ngetahui potensi tegakan pada masa yang akan datang, model ini dapat digunakan untuk mengetahui riap dan daur volume (maksimum) dalam pengelolaan hutan rakyat kayu bawang di Provinsi Bengkulu.

\section{BAHAN DAN METODE}

Penelitian dilakukan dengan membangun petak-petak ukur permanen (PUP) di beberapa Kecamatan di Kabupaten Bengkulu Utara, Provinsi Bengkulu. PUP dibangun sebanyak 17 PUP dengan rincian 2 PUP terdapat di Desa Pasar Pedati, Kecamatan Pekik Nyaring, 4 PUP di Desa Sawang Lebar, Kecamatan Air Napal, dan 11 PUP di Desa Dusun Curup, Kecamatan Air Besi (Tabel 1). Bahan yang digunakan dalam penelitian ini adalah tegakan kayu bawang pada 17 PUP berukuran $30 \mathrm{~m}$ × $30 \mathrm{~m}(0,09$ ha) dan $40 \mathrm{~m}$ x $40 \mathrm{~m}(0,16 \mathrm{ha})$ yang dibuat pada tahun 2005 (6 PUP) dan 2006 (11 PUP). Pengamatan dilakukan pada tahun 2005, 2006, 2007, dan 2009 terhadap variabel tinggi dan keliling tegakan.

Penyusunan model dilakukan dengan analisis regresi berganda dengan variabel bebas umur dan kerapatan tegakan. Variabel yang diduga adalah diameter, tinggi, peninggi, luas bidang dasar, dan volume tegakan. Metode analisis regresi yang dilakukan adalah metode regresi biasa (Ordinary Least Square $=$ OLS) dan metode regresi terboboti (Weighted Least Square = WLS) (Draper and Smith 1992; Gujarati 1978; Chatterjee and Price 1938). Kedua metode regresi ini digunakan karena data yang digunakan merupakan gabungan data serial dan data cross sectional, sehingga perlu diketahui metode regresi yang lebih efektif.

Model yang digunakan adalah model Schumacher dalam Van Laar dan Akca (1997); Clutter et al. (1983) dan model Wiroatmojo (1984) sebagai berikut: 
Model Schumacher (1939):

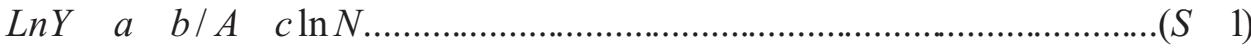

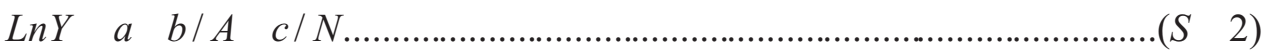

Model Wiroatmodjo (1984)

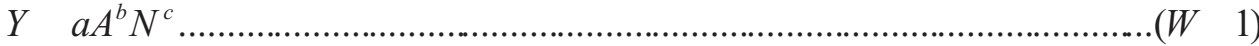

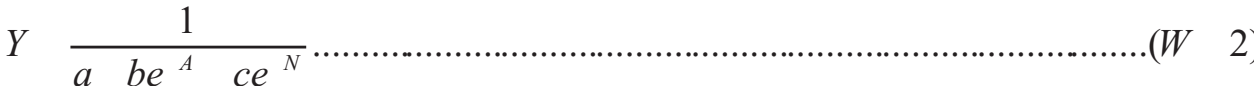

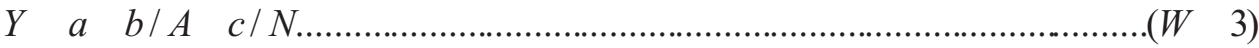

Keterangan:

$\mathrm{Y}=$ dimensi tegakan: tinggi $(\mathrm{m})$, diameter $(\mathrm{cm})$, dan volume $\left(\mathrm{m}^{3} / \mathrm{ha}\right) ; \mathrm{A}=$ umur tegakan (tahun); $\mathrm{N}=$ kerapatan tegakan (individu/ha); a, b, c = konstanta, e = bilangan natural; S-1, S-2 = Model Schumacher 1 dan 2, W-1, W-2; W-3 = model Wiroatmodjo 1, 2, dan 3 .

Tabel(Table) 1. Lokasi, letak geografis, ketinggian tempat, dan kelerengan PUP hutan rakyat kayu bawang di Provinsi Bengkulu (Location, geographical location, altitude, and slope

\begin{tabular}{|c|c|c|c|c|}
\hline $\begin{array}{l}\text { Lokasi (desa, kecamatan, kabupaten) } \\
\text { (Location (village, district, county)) }\end{array}$ & $\begin{array}{l}\text { No. } \\
\text { PUP }\end{array}$ & Letak Geografis & $\begin{array}{l}\text { Alti- } \\
\text { tude } \\
(\mathrm{m})\end{array}$ & $\begin{array}{l}\text { Kemiringan } \\
\text { lapangan }\left({ }^{\circ}\right)\end{array}$ \\
\hline \multirow{2}{*}{$\begin{array}{l}\text { Pasar Pedati, Pekik Nyaring, } \\
\text { Bengkulu Utara }\end{array}$} & 1 & $102^{\circ} 15^{\prime} 10^{\prime \prime} \mathrm{BT} ; 03^{\circ} 43^{\prime} 59^{\prime \prime} \mathrm{LS}$ & 24 & 0 \\
\hline & 2 & $102^{\circ} 15^{\prime} 10^{\prime \prime} \mathrm{BT} ; 03^{\circ} 43^{\prime} 54^{\prime \prime} \mathrm{LS}$ & 24 & 0 \\
\hline \multirow{4}{*}{$\begin{array}{l}\text { Sawang Lebar, Air Napal, } \\
\text { Bengkulu Utara. }\end{array}$} & 3 & $102^{\circ} 10^{\prime} 49^{\prime \prime} \mathrm{BT} ; 03^{\circ} 35^{\prime} 07^{\prime \prime} \mathrm{LS}$ & 56 & 15 \\
\hline & 4 & $102^{\circ} 10^{\prime} 49^{\prime \prime} \mathrm{BT} ; 03^{\circ} 35^{\prime} 07^{\prime \prime} \mathrm{LS}$ & 56 & 15 \\
\hline & 5 & $102^{\circ} 11^{\prime} 15^{\prime \prime} \mathrm{BT} ; 03^{\circ} 35^{\prime} 36^{\prime \prime} \mathrm{LS}$ & 46 & 26 \\
\hline & 6 & $102^{\circ} 11^{\prime} 15^{\prime \prime} \mathrm{BT} ; 03^{\circ} 35^{\prime} 36^{\prime \prime} \mathrm{LS}$ & 46 & 25 \\
\hline \multirow{11}{*}{$\begin{array}{l}\text { Dusun Curup, Air Besi, Bengkulu } \\
\text { Utara. }\end{array}$} & 7 & $102^{\circ} 11^{\prime} 53$ " BT; $03^{\circ} 31^{\prime} 50$ ” LS & 86 & 15 \\
\hline & 8 & $102^{\circ} 10^{\prime} 50^{\prime \prime} \mathrm{BT} ; 03^{\circ} 31^{\prime} 16^{\prime \prime} \mathrm{LS}$ & 91 & 0 \\
\hline & 9 & $102^{\circ} 11^{\prime} 01$ " BT; $03^{\circ} 31^{\prime} 18^{\prime \prime} \mathrm{LS}$ & 95 & 25 \\
\hline & 10 & $102^{\circ} 11^{\prime} 16^{\prime \prime} \mathrm{BT} ; 03^{\circ} 31^{\prime} 00^{\prime \prime} \mathrm{LS}$ & 88 & 27 \\
\hline & 11 & $102^{\circ} 11^{\prime} 20^{\prime \prime} \mathrm{BT} ; 03^{\circ} 30^{\prime} 54^{\prime \prime} \mathrm{LS}$ & 86 & 5 \\
\hline & 12 & $102^{\circ} 11^{\prime} 20^{\prime \prime} \mathrm{BT} ; 03^{\circ} 30^{\prime} 54^{\prime \prime} \mathrm{LS}$ & 86 & 5 \\
\hline & 13 & $102^{\circ} 11^{\prime} 20^{\prime \prime} \mathrm{BT} ; 03^{\circ} 30^{\prime} 54^{\prime \prime} \mathrm{LS}$ & 86 & 10 \\
\hline & 14 & $102^{\circ} 12^{\prime} 07^{\prime \prime} \mathrm{BT} ; 03^{\circ} 31^{\prime} 08^{\prime \prime} \mathrm{LS}$ & 106 & 17 \\
\hline & 15 & $102^{\circ} 12^{\prime} 20{ }^{\prime \prime} \mathrm{BT} ; 03^{\circ} 31^{\prime} 09^{\prime \prime} \mathrm{LS}$ & 106 & 30 \\
\hline & 16 & $102^{\circ} 12^{\prime} 10^{\prime \prime} \mathrm{BT} ; 03^{\circ} 31^{\prime} 14^{\prime \prime} \mathrm{LS}$ & 106 & 0 \\
\hline & 17 & $102^{\circ} 12^{\prime} 11^{\prime \prime} \mathrm{BT} ; 03^{\circ} 31^{\prime} 14^{\prime \prime} \mathrm{LS}$ & 106 & 0 \\
\hline
\end{tabular}
forest timber PUP onion in Bengkulu Province)

Model terbaik dipilih berdasarkan kriteriakriteria uji sebagai berikut:

a. Uji Tingkat Kepentingan peranan peubah bebas Uji ini bertujuan untuk mengetahui peranan peubah bebas dalam model, yaitu besarnya peluang untuk menolak Ho padahal Ho benar (Johnson dan Bhattacharyya 1992). Kriteria yang digunakan adalah:

Ho : $\beta \mathrm{i}=0$ untuk semua $i$, terima jika $p>\alpha$

$\mathrm{H}_{1}$ : setidak-tidaknya ada satu $\beta \mathrm{i} \neq 0$, terima jika $\mathrm{p} \leq \alpha$ b. Koefisien determinasi $\left(\mathrm{R}^{2}\right)$

Koefisien determinasi merupakan proporsi variasi total di sekitar nilai tengah y yang dapat dijelaskan oleh regresi (Draper dan Smith 1992). Makin tinggi nilai $\mathrm{R}^{2}$, makin besar variasi yang dapat dijelaskan. $\mathrm{R}^{2}$ dihitung dengan rumus:

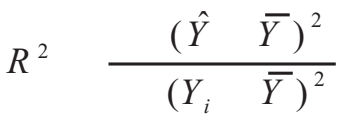


c. Simpangan rata-rata (SR) dan simpangan agregat (SA)

Simpangan rata-rata dan simpangan agregat digunakan untuk mengukur keakuratan suatu model penduga pertumbuhan tegakan yang besarnya ditentukan oleh selisih nilai hasil pendugaan dan hasil pengukuran (data). Semakin kecil nilai simpangan rata-rata dan simpangan agregat suatu model maka keakuratan model tersebut semakin tinggi (Husch 1963). Nilai SR dan SA dihitung dengan rumus:

$S R \frac{\frac{\mid Y_{i} \quad \hat{Y}_{i}}{\mid}}{Y_{i}} \times 100 \%$ SA $\frac{\hat{Y}_{i} Y_{i}}{\hat{Y}_{i}} \times 100 \%$

d. Bias (mean error $=\mathrm{ME}$ ) dan akar rata-rata kuadrat simpangan (root mean squared error $=$ RMSE)

Bias menyatakan rata-rata kesalahan tanpa melihat tandanya (negatif atau positif), sedangkan RMSE menyatakan akurasi dugaan (Huang et al., 2003) yang dinyatakan dengan rumus:

$$
M E \quad \frac{1}{n} \quad Y_{i} \quad \hat{Y}_{i} \quad R M S E \sqrt{\left.\frac{\left(Y_{i}\right.}{n} \hat{Y}_{i}\right)^{2}}
$$

Keterangan: $n=$ Jumlah unit contoh, $p=$ jumlah parameter, $Y_{i}=$ nilai pengukuran variabel ke-i, $\hat{Y}_{i}=$ nilai dugaan variabel ke-i.

\section{HASIL DAN PEMBAHASAN}

\section{A. Hasil}

\section{Model Pertumbuhan Tegakan pada setiap Pola Tanam}

a. Model Pertumbuhan Diameter Tegakan

Hasil analisis regresi dengan metode OLS dan WLS terhadap variabel diameter tegakan pada pola tanam agroforestry kayu bawang + kopi dan agroforestry multi jenis membentuk persamaan dengan parameter yang relatif sama pada semua model yang diuji (Tabel 2). Berdasarkan hasil uji statistik (Tabel 3), modelmodel yang diujikan mempunyai kemampuan yang tinggi dalam menerangkan keragaman dalam variabel diameter tegakan pada kedua pola tanam. Hal ini ditunjukkan oleh koefisien determinasi yang tinggi, yaitu $80 \%-98 \%$. Hasil uji statistik (Tabel 3) juga menunjukkan bahwa model pertumbuhan tegakan pada kedua pola tanam berbeda, pada pola agroforestry kayu bawang + kopi, model terbaik adalah model berpangkat (W-1) yaitu $\mathrm{D}=44,710 \mathrm{~A}^{0,44807} \mathrm{~N}^{-0,28443}$ $\left(\mathrm{R}^{2}\right.$ 98,0\%; SA 0,60; SR 4,87; ME 0,113; dan RMSE 0,992 , sedangkan pada pola agroforestry multi jenis, model terbaik adalah model S-2 yaitu $\mathrm{Ln} \mathrm{D}=2,644-1,290 / \mathrm{A}+111,37 / \mathrm{N}\left(\mathrm{R}^{2}\right.$ 92,2\%; SA 1,84; SR 4,76; ME 0,254; dan RSME 0,899). Model-model tersebut dapat secara akurat menduga besarnya diameter tegakan pada umur daur atau pada umur tertentu sehingga perencanaan pemanenan dapat dilakukan dengan tepat.

Tabel(Table)2. Rekapitulasi hasil analisis regresi model pertumbuhan diameter tegakan pada dua pola tanam Kayu Bawang di Propinsi Bengkulu (Regression analysis result recapitulation of diametre growth model for two Kayu Bawang planting pattern in Bengkulu Province)

\begin{tabular}{|c|c|c|}
\hline \multirow{2}{*}{ Model } & \multicolumn{2}{|c|}{ Persamaan } \\
\hline & OLS & WLS \\
\hline \multicolumn{3}{|c|}{ Pola tanam I: agroforestry kayu bawang + kopi } \\
\hline S-1 & $\operatorname{Ln} \mathrm{D}=5,043-2,022 / \mathrm{A}-0,296 \ln \mathrm{N}$ & $\operatorname{Ln} \mathrm{D}=4,834-2,021 / \mathrm{A}-0,257 \ln \mathrm{N}$ \\
\hline $\mathrm{S}-2$ & $\operatorname{Ln} \mathrm{D}=3,0035-2,088 / \mathrm{A}+106,6 / \mathrm{N}$ & $\operatorname{Ln} \mathrm{D}=3,0458-2,062 / \mathrm{A}+96,7 / \mathrm{N}$ \\
\hline $\mathrm{W}-1$ & $\mathrm{D}=45,95198 \mathrm{~A}^{0,4511} \mathrm{~N}^{-0,29667}$ & $\mathrm{D}=44,7101 \mathrm{~A}^{0,44807} \mathrm{~N}^{-0,28443}$ \\
\hline $\mathrm{W}-2$ & $\mathrm{D}=1 /\left(0,060+0,396 \mathrm{e}^{-\mathrm{A}}-0,207 \mathrm{e}^{-\mathrm{N} / 100}\right)$ & $\mathrm{D}=1 /\left(0,056+0,406 \mathrm{e}^{-\mathrm{A}}-0,205 \mathrm{e}^{-\mathrm{N} / 100}\right)$ \\
\hline $\mathrm{W}-3$ & $\mathrm{D}=21,389-36,798 / \mathrm{A}+1644,9 / \mathrm{N}$ & $\mathrm{D}=21,248-31,973 / \mathrm{A}+1317,2 / \mathrm{N}$ \\
\hline \multicolumn{3}{|c|}{ Pola tanam II: agroforestry multi jenis } \\
\hline S-1 & $\operatorname{Ln} \mathrm{D}=4,846-1,554 / \mathrm{A}-0,294 \ln \mathrm{N}$ & $\operatorname{Ln} \mathrm{D}=4,337-1,451 / \mathrm{A}-0,223 \ln \mathrm{N}$ \\
\hline $\mathrm{S}-2$ & $\operatorname{Ln} D=2,6625-1,367 / \mathrm{A}+116,97 / \mathrm{N}$ & $\operatorname{Ln} D=2,646-1,290 / \mathrm{A}+111,37 / \mathrm{N}$ \\
\hline $\mathrm{W}-1$ & $\mathrm{D}=26,9289 \mathrm{~A}^{0,43944} \mathrm{~N}^{-0,2151}$ & $\mathrm{D}=19,1232 \mathrm{~A}^{0,43470} \mathrm{~N}^{-0,16312}$ \\
\hline $\mathrm{W}-2$ & $\mathrm{D}=1 /\left(0,079+0,280 \mathrm{e}^{-\mathrm{A}}-0,210 \mathrm{e}^{-\mathrm{N} / 100}\right)$ & $\mathrm{D}=1 /\left(0,080+0,270 \mathrm{e}^{-\mathrm{A}}-0,213 \mathrm{e}^{-\mathrm{N} / 100}\right)$ \\
\hline W-3 & $\mathrm{D}=13,2254-16,320 / \mathrm{A}+2246,4 / \mathrm{N}$ & $\mathrm{D}=13,2945-16,514 / \mathrm{A}+1723,7 / \mathrm{N}$ \\
\hline
\end{tabular}


Hasil uji statistik (Tabel 3) juga menunjukkan bahwa model pertumbuhan tegakan pada kedua pola tanam berbeda, pada pola agroforestry kayu bawang + kopi, model terbaik adalah model berpangkat (W-1) yaitu $\mathrm{D}=44,710 \mathrm{~A}^{0,4807} \mathrm{~N}^{-0,2843}\left(\mathrm{R}^{2} 98,0 \%\right.$; SA 0,60; SR 4,87; ME 0,113; dan RMSE 0,992, sedangkan pada pola agroforestry multi jenis, model terbaik adalah model S-2 yaitu $\mathrm{Ln} \mathrm{D}=2,644$ $1,290 / \mathrm{A}+111,37 / \mathrm{N}\left(\mathrm{R}^{2} 92,2 \%\right.$; SA 1,84 ; SR 4,76; ME 0,254; dan RSME 0,899). Modelmodel tersebut dapat secara akurat menduga besarnya diameter tegakan pada umur daur atau pada umur tertentu sehingga perencanaan pemanenan dapat dilakukan dengan tepat.

Tabel(Table) 3. Nilai uji statistik model pertumbuhan diameter tegakan dua pola tanam kayu bawang di Provinsi Bengkulu dengan metode OLS dan WLS (Statistic test value of diameter growth model for two Kayu Bawang planting pattern in Bengkulu Province by OLS and WLS methods)

\begin{tabular}{|c|c|c|c|c|c|c|c|c|c|}
\hline \multirow{2}{*}{ Model } & \multirow{2}{*}{$\begin{array}{c}\text { Metode } \\
\text { regresi }\end{array}$} & \multirow{2}{*}{$\mathrm{R}^{2}(\%)$} & \multicolumn{3}{|c|}{ P-value } & \multirow{2}{*}{$\mathrm{SA}(\%)$} & \multirow{2}{*}{$\mathrm{SR}(\%)$} & \multirow{2}{*}{$\mathrm{ME}$} & \multirow{2}{*}{ RMSE } \\
\hline & & & $\mathrm{A}$ & $\mathrm{b}$ & $\mathrm{C}$ & & & & \\
\hline \multicolumn{10}{|c|}{ Pola tanam I: agroforestry kayu bawang + kopi } \\
\hline \multirow[t]{2}{*}{ S-1 } & OLS & 92,5 & $* *$ & $* *$ & $* *$ & 0,43 & 6,43 & 0,081 & 1,298 \\
\hline & WLS & 94,3 & $* *$ & ** & $* *$ & $-1,21$ & 6,41 & $-0,228$ & 1,326 \\
\hline \multirow[t]{2}{*}{$\mathrm{S}-2$} & OLS & 91,3 & $* *$ & $* *$ & $* *$ & 0,43 & 7,12 & 0,080 & 1,392 \\
\hline & WLS & 93,8 & $* *$ & $* *$ & $* *$ & $-1,08$ & 7,06 & $-0,203$ & 1,409 \\
\hline \multirow[t]{2}{*}{ W-1 } & OLS & 96,0 & $* *$ & $* *$ & $* *$ & 0,12 & 4,92 & 0,022 & 0,994 \\
\hline & WLS & 98,0 & $* *$ & $* *$ & $* *$ & 0,60 & 4,87 & 0,113 & 0,992 \\
\hline \multirow[t]{2}{*}{ W-2 } & OLS & 80,0 & $* *$ & $* *$ & $* *$ & 2,39 & 11,40 & 0,452 & 2,592 \\
\hline & WLS & 88,2 & $* *$ & $* *$ & $* *$ & $-4,56$ & 12,32 & $-0,862$ & 2,632 \\
\hline \multirow[t]{2}{*}{ W-3 } & OLS & 86,2 & $* *$ & $* *$ & $* *$ & 0,00 & 8,66 & $-0,000$ & 1,794 \\
\hline & WLS & 84,0 & $* *$ & $* *$ & $*$ & 0,85 & 8,83 & 0,160 & 1,915 \\
\hline \multicolumn{10}{|c|}{ Pola tanam II: agroforestry multi jenis } \\
\hline \multirow[t]{2}{*}{ S-1 } & OLS & 95,5 & $* *$ & $* *$ & $* *$ & 0,44 & 5,79 & 0,061 & 0,923 \\
\hline & WLS & 86,9 & $* *$ & $* *$ & $* *$ & 4,71 & 7,15 & 0,647 & 1,826 \\
\hline \multirow[t]{2}{*}{$\mathrm{S}-2$} & OLS & 97,2 & $* *$ & $* *$ & $* *$ & 0,15 & 4,67 & 0,020 & 0,786 \\
\hline & WLS & 92,2 & $* *$ & $* *$ & $* *$ & 1,84 & 4,76 & 0,254 & 0,899 \\
\hline \multirow[t]{2}{*}{ W-1 } & OLS & 96,4 & $* *$ & $* *$ & $* *$ & 0,32 & 5,46 & 0,044 & 0,881 \\
\hline & WLS & 89,4 & $* *$ & $* *$ & $* *$ & 2,89 & 5,77 & 0,397 & 1,394 \\
\hline \multirow[t]{2}{*}{ W-2 } & OLS & 90,5 & $* *$ & $* *$ & $* *$ & $-0,32$ & 8,25 & $-0,044$ & 2,306 \\
\hline & WLS & 90,5 & $* *$ & $* *$ & $* *$ & $-0,04$ & 8,25 & $-0,005$ & 2,351 \\
\hline \multirow[t]{2}{*}{ W-3 } & OLS & 97,9 & $* *$ & $* *$ & $* *$ & 0,01 & 5,57 & 0,001 & 0,791 \\
\hline & WLS & 84,2 & $* *$ & $* *$ & $* *$ & 4,06 & 6,66 & 0,558 & 1,452 \\
\hline
\end{tabular}

Keterangan : $\mathrm{R}^{2}=$ koef. determinasi, $\mathrm{SA}=$ simp. agregat, $\mathrm{SR}=$ simp. rata-rata, $\mathrm{ME}=$ bias, $\mathrm{RMSE}=$ akar rata-rata kuadrat simpangan, $\operatorname{tn}=$ tidak nyata $(\mathrm{P}>0,05), *=$ nyata $(\mathrm{p}<0,05),{ }^{* *}=$ sangat nyata $(\mathrm{p}<0,01)$

\section{b. Model Pertumbuhan tinggi tegakan}

Hasil analisis regresi dengan metode OLS dan WLS pada model-model pertumbuhan tinggi tegakan yang diujikan memberikan nilai-nilai parameter yang relatif sama (Tabel 4). Model terbaik yang diberikan oleh kedua metode analisis tidak berbeda, yaitu model W-1 (berpangkat), yaitu $\mathrm{H}=30,411 \mathrm{~A}^{0,39637} \mathrm{~N}^{-0,22306}\left(\mathrm{R}^{2} 79,3 \%\right.$; $\mathrm{SA}$
0,13; SR 10,70; ME 0,022; RMSE 2,365) untuk pola tanam kayu bawang + kopi dan $\mathrm{H}=8,435$ $\mathrm{A}^{0,48802} \mathrm{~N}^{-0,03989}\left(\mathrm{R}^{2}\right.$ 95,0\%; SA 1,64; SR 4,13; ME 0,231; RMSE 0,957) untuk agroforestry multijenis (Tabel 4 dan 5). Nilai-nilai uji statistik ini menunjukkan bahwa pendugaan tinggi tegakan pada kedua pola tanam kayu bawang dapat dilakukan secara akurat. 
Tabel(Table) 4. Rekapitulasi hasil analisis regresi model pertumbuhan tinggi tegakan pada dua pola tanam kayu bawang di Propinsi Bengkulu (Regression analysis result recapitulation of height growth model for two Kayu Bawang planting pattern in Bengkulu Province)

\begin{tabular}{|c|c|c|}
\hline \multirow{2}{*}{ Model } & \multicolumn{2}{|c|}{ Persamaan } \\
\hline & OLS & WLS \\
\hline \multicolumn{3}{|c|}{ Pola tanam I: agroforestry kayu bawang + kopi } \\
\hline $\begin{array}{l}\text { S-1 } \\
\text { S-2 } \\
\text { W-1 } \\
\text { W-2 } \\
\text { W-3 }\end{array}$ & $\begin{array}{l}\mathrm{Ln} H=4,210-1,798 / \mathrm{A}-0,182 \ln \mathrm{N} \\
\mathrm{Ln} H=2,979-1,862 / \mathrm{A}+59,59 / \mathrm{N} \\
\mathrm{H}=25,613 \mathrm{~A}^{0,38726} \mathrm{~N}^{-0,19174} \\
\mathrm{H}=1 /\left(0,062+0,413 \mathrm{e}^{-\mathrm{A}}-0,125 \mathrm{e}^{-\mathrm{N} / 100}\right) \\
\mathrm{H}=20,309-29,181 / \mathrm{A}+751,9 / \mathrm{N}\end{array}$ & $\begin{array}{l}\text { Ln } H=4,301-1,710 / \mathrm{A}-0,201 \ln \mathrm{N} \\
\mathrm{Ln} H=2,928-1,773 / \mathrm{A}+69,36 / \mathrm{N} \\
\mathrm{H}=30,411 \mathrm{~A}^{0,39637} \mathrm{~N}^{-0,22306} \\
\mathrm{H}=1 /\left(0,062+0,537 \mathrm{e}^{-\mathrm{A}}-0,156 \mathrm{e}^{-\mathrm{N} / 100}\right) \\
\mathrm{H}=18,815-25,328 / \mathrm{A}+919,6 / \mathrm{N}\end{array}$ \\
\hline \multicolumn{3}{|c|}{ Pola tanam II: agroforestry multi jenis } \\
\hline $\begin{array}{c}\text { S-1 } \\
\text { S-2 } \\
\text { W-1 } \\
\text { W-2 } \\
\text { W-3 }\end{array}$ & $\begin{array}{l}\mathrm{Ln} H=4,026-1,727 / \mathrm{A}-0,152 \ln \mathrm{N} \\
\mathrm{Ln} H=2,879-1,595 / \mathrm{A}+64,63 / \mathrm{N} \\
\mathrm{H}=9,45932 \mathrm{~A}^{0,49976} \mathrm{~N}^{-0,05883} \\
\mathrm{H}=1 /\left(0,071+0,300 \mathrm{e}^{-\mathrm{A}}-0,142 \mathrm{e}^{-\mathrm{N} / 100}\right) \\
\mathrm{H}=16,479-19,989 / \mathrm{A}+1320,7 / \mathrm{N}\end{array}$ & $\begin{array}{l}\text { Ln } H=3,654-1,700 / \mathrm{A}-0,097 \ln \mathrm{N} \\
\mathrm{Ln} H=2,917-1,623 / \mathrm{A}+50,12 / \mathrm{N} \\
\mathrm{H}=8,43509 \mathrm{~A}^{0,48802} \mathrm{~N}^{-0,03989} \\
\mathrm{H}=1 /\left(0,068+0,335 \mathrm{e}^{-\mathrm{A}}-0,119 \mathrm{e}^{-\mathrm{N} / 100}\right) \\
\mathrm{H}=16,888-18,745 / \mathrm{A}+849,40 / \mathrm{N}\end{array}$ \\
\hline
\end{tabular}

Keterangan: $\mathrm{H}=$ tinggi tegakan, $\mathrm{A}=$ umur, dan $\mathrm{N}=$ kerapatan tegakan

Tabel(Table) 5. Nilai uji statistik model pertumbuhan tinggi tegakan dua pola tanam kayu bawang di Propinsi Bengkulu dengan metode OLS dan WLS (Statistic test value of height growth model for two Kayu Bawang planting pattern in Bengkulu Province by OLS and WLS methods)

\begin{tabular}{|c|c|c|c|c|c|c|c|c|c|}
\hline \multirow[t]{2}{*}{ Model } & \multirow{2}{*}{$\begin{array}{c}\text { Metode } \\
\text { regresi }\end{array}$} & \multirow[t]{2}{*}{$\mathrm{R}^{2}(\%)$} & \multicolumn{3}{|c|}{ P-value } & \multirow[t]{2}{*}{ SA $(\%)$} & \multirow[t]{2}{*}{ SR $(\%)$} & \multirow[t]{2}{*}{$\mathrm{ME}$} & \multirow[t]{2}{*}{ RMSE } \\
\hline & & & $\mathrm{A}$ & $\mathrm{B}$ & $\mathrm{C}$ & & & & \\
\hline \multicolumn{10}{|c|}{ Pola tanam I: agroforestry kayu bawang + kopi } \\
\hline \multirow[t]{2}{*}{ S-1 } & OLS & 73,6 & $* *$ & $* *$ & $\operatorname{tn}$ & 0,95 & 10,86 & 0,158 & 2,405 \\
\hline & WLS & 79,2 & $* *$ & $* *$ & $*$ & 1,29 & 10,79 & 0,215 & 2,426 \\
\hline \multirow[t]{2}{*}{$\mathrm{S}-2$} & OLS & 72,4 & $* *$ & $* *$ & $*$ & 0,97 & 11,11 & 0,161 & 2,437 \\
\hline & WLS & 77,8 & $* *$ & $* *$ & $*$ & 1,24 & 11,09 & 0,205 & 2,459 \\
\hline \multirow[t]{2}{*}{ W-1 } & OLS & 74,0 & $* *$ & $* *$ & $\operatorname{tn}$ & 0,83 & 10,55 & 0,137 & 2,344 \\
\hline & WLS & 79,3 & $* *$ & $* *$ & $* *$ & 0,13 & 10,70 & 0,022 & 2,365 \\
\hline \multirow[t]{2}{*}{$\mathrm{W}-2$} & OLS & 70,9 & $* *$ & $* *$ & tn & 2,70 & 12,13 & 0,448 & 2,865 \\
\hline & WLS & 60,5 & $* *$ & $* *$ & $*$ & 1,54 & 12,99 & 0,255 & 2,810 \\
\hline \multirow[t]{2}{*}{ W-3 } & OLS & 63,1 & $* *$ & $* *$ & tn & 0,00 & 12,54 & 0,000 & 2,493 \\
\hline & WLS & 72,3 & $* *$ & $* *$ & tn & 1,07 & 12,15 & 0,178 & 2,523 \\
\hline \multicolumn{10}{|c|}{ Pola tanam II: agroforestry multi jenis } \\
\hline \multirow[t]{2}{*}{ S-1 } & OLS & 92,8 & $* *$ & $* *$ & $* *$ & 0,41 & 5,47 & 0,058 & 1,006 \\
\hline & WLS & 88,8 & $* *$ & $* *$ & $*$ & 2,16 & 6,27 & 0,305 & 1,415 \\
\hline \multirow[t]{2}{*}{$\mathrm{S}-2$} & OLS & 95,1 & $* *$ & $* *$ & $* *$ & 0,27 & 4,94 & 0,039 & 0,839 \\
\hline & WLS & 91,5 & $* *$ & $* *$ & $* *$ & 0,76 & 4,92 & 0,107 & 0,995 \\
\hline \multirow[t]{2}{*}{$\mathrm{W}-1$} & OLS & 96,4 & $* *$ & $* *$ & $*$ & 0,22 & 4,19 & 0,031 & 0,781 \\
\hline & WLS & 95,0 & $* *$ & $* *$ & tn & 1,64 & 4,13 & 0,231 & 0,957 \\
\hline \multirow[t]{2}{*}{ W-2 } & OLS & 90,0 & $* *$ & $* *$ & $* *$ & 0,61 & 6,80 & 0,087 & 1,619 \\
\hline & WLS & 86,2 & $* *$ & $* *$ & $* *$ & $-0,46$ & 7,18 & $-0,065$ & 1,445 \\
\hline \multirow[t]{2}{*}{ W-3 } & OLS & 94,7 & $* *$ & $* *$ & $* *$ & 0,01 & 6,01 & 0,002 & 0,986 \\
\hline & WLS & 87,6 & $* *$ & $* *$ & $*$ & 1,80 & 6,57 & 0,255 & 1,390 \\
\hline
\end{tabular}

Keterangan : $\mathrm{R}^{2}=$ koef. determinasi, $\mathrm{SA}=$ simp. agregat, $\mathrm{SR}=$ simp. rata-rata, $\mathrm{ME}=$ bias, $\mathrm{RMSE}=$ akar rata-rata kuadrat simpangan, $\mathrm{tn}=$ tidak nyata $(\mathrm{p}>0,05), *=$ nyata $(\mathrm{p}<0,05), * *=$ sangat nyata $(\mathrm{p}<0,01)$ 


\section{c. Model Pertumbuhan Volume Tegakan}

Analisis regresi metode OLS dan WLS terhadap variabel volume tegakan pada kedua pola tanam kayu bawang membentuk persamaan dengan parameter yang relatif sama pada semua model yang diuji (Tabel 6). Kemampuan model menerangkan keragaman volume tegakan pada kedua pola tanam bervariasi sebagaimana ditunjukkan oleh variasi koefisien determinasi $\left(\mathrm{R}^{2}\right)$. Metode OLS memberikan kisaran nilai $\mathrm{R}^{2}$ sebesar $69,9 \%$ - $89,6 \%$ (pola tanam kayu bawang + kopi) dan $77,7 \%$ - 92,6\% (pola tanam agroforestry multijenis). Metode WLS memberikan kisaran 53,9\% - 92,5\% (pola tanam kayu bawang + kopi) dan 69,5\% - 97,7\% (pola tanam groforestry multijenis) (Tabel 7).

Volume tegakan merupakan gambaran nilai ekonomi yang dapat diperoleh dari penanaman kayu bawang sehingga model penduga yang akurat akan bermanfaat untuk menentukan besarnya volume yang dapat dipanen dan berapa pendapatan yang diperoleh.

Hasil uji statistik pada Tabel 7 juga menunjukkan bahwa model pertumbuhan volume tegakan terbaik pada kedua pola tanam adalah model W-1 (berpangkat). Namun demikian, dari aspek kelogisan model, model ini kurang tepat untuk menggambarkan pola pertumbuhan ideal karena mempunyai nilai eksponen dari A (umur) yang lebih besar dari 1, yang menunjukkan pertumbuhan eksponensial dan tidak memiliki asimptot. Berdasarkan alasan ini model S-2 yaitu $\mathrm{Ln} \mathrm{V}=6,224-6,889 / \mathrm{A}$ 133,85/N (R² 88,0\%; SA -4,50; SR 19,19; ME 4,090; RMSE 19,181) dipilih sebagai model terbaik pada pola tanam kayu bawang + kopi dan model S-1, Ln V = 4,001 - 4,761/A + 0,219 $\ln \mathrm{N}$ $\left(\mathrm{R}^{2} 89,9 \%\right.$; SA -1,04; SR 14,10; ME -0,765; RMSE 10,859) untuk pola tanam agroforestry multijenis.

Tabel(Table) 6. Rekapitulasi hasil analisis regresi model pertumbuhan volume tegakan pada dua pola tanam kayu bawang di Propinsi Bengkulu (Regression analysis result recapitulation of volume growth model for two Kayu Bawang planting pattern in Bengkulu Province)

\begin{tabular}{|c|c|c|}
\hline \multirow{2}{*}{ Model } & \multicolumn{2}{|c|}{ Persamaan } \\
\hline & OLS & WLS \\
\hline \multicolumn{2}{|c|}{ Pola tanam I: agroforestry kayu bawang + kopi } & \\
\hline S-1 & $\operatorname{Ln} V=3,007-5,575 / A+0,431 \ln N$ & $\operatorname{Ln} V=3,965-6,840 / A+0,315 \ln \mathrm{N}$ \\
\hline $\mathrm{S}-2$ & $\operatorname{Ln} \mathrm{V}=6,090-5,586 / \mathrm{A}-183,74 / \mathrm{N}$ & $\operatorname{Ln} V=6,224-6,889 / \mathrm{A}-133,85 / \mathrm{N}$ \\
\hline $\mathrm{W}-1$ & $\mathrm{~V}=0,8446 \mathrm{~A}^{1,23335} \mathrm{~N}^{0,4217}$ & $\mathrm{~V}=0,9292 \mathrm{~A}^{1,26885} \mathrm{~N}^{0,3974}$ \\
\hline $\mathrm{W}-2$ & $\mathrm{~V}=1 /\left(0,006+0,255 \mathrm{e}^{-\mathrm{A}}+0,084 \mathrm{e}^{-\mathrm{N} / 100}\right)$ & $\mathrm{V}=1 /\left(0,007+0,345 \mathrm{e}^{-\mathrm{A}}+0,008 \mathrm{e}^{-\mathrm{N} / 100}\right)$ \\
\hline W-3 & $\mathrm{V}=215,2-425,23 / \mathrm{A}-11776 / \mathrm{N}$ & $\mathrm{V}=180,84-320,01 / \mathrm{A}-9757 / \mathrm{N}$ \\
\hline \multicolumn{2}{|c|}{ Pola tanam II: agroforestry multi jenis } & \\
\hline S-1 & $\operatorname{Ln} V=3,687-4,579 / A+0,258 \ln \mathrm{N}$ & $\operatorname{Ln} V=4,001-4,761 / A+0,219 \ln N$ \\
\hline $\mathrm{S}-2$ & $\operatorname{Ln} V=5,500-4,538 / A-79,02 / \mathrm{N}$ & $\operatorname{Ln} V=5,568-4,744 / \mathrm{A}-74,72 / \mathrm{N}$ \\
\hline $\mathrm{W}-1$ & $\mathrm{~V}=0,3857 \mathrm{~A}^{1,30855} \mathrm{~N}^{0,49592}$ & $\mathrm{~V}=0,618 \mathrm{~A}^{1,27968} \mathrm{~N}^{0,42756}$ \\
\hline $\mathrm{W}-2$ & $\mathrm{~V}=1 /\left(0,010+0,248 \mathrm{e}^{-\mathrm{A}}-0,004 \mathrm{e}^{-\mathrm{N} / 100}\right)$ & $\mathrm{V}=1 /\left(0,008+0,274 \mathrm{e}^{-\mathrm{A}}-0,005 \mathrm{e}^{-\mathrm{N} / 100}\right)$ \\
\hline W-3 & $\mathrm{V}=143,56-251,9 / \mathrm{A}-3057 / \mathrm{N}$ & $\mathrm{V}=142,63-234,83 / \mathrm{A}-2727 / \mathrm{N}$ \\
\hline
\end{tabular}

Keterangan : $\mathrm{V}=$ volume tegakan, $\mathrm{A}=$ umur, dan $\mathrm{N}=$ kerapatan tegakan 
Tabel(Table) 7. Nilai uji statistik model pertumbuhan volume tegakan dua pola tanam kayu bawang di Provinsi Bengkulu dengan metode OLS dan WLS (Statistic test value of volume growth model for two kayu bawang planting pattern in Bengkulu Province by OLS and WLS methods)

\begin{tabular}{|c|c|c|c|c|c|c|c|c|c|}
\hline \multirow[t]{2}{*}{ Model } & \multirow{2}{*}{$\begin{array}{l}\text { Metode } \\
\text { regresi }\end{array}$} & \multirow[t]{2}{*}{$\mathrm{R}^{2}(\%)$} & \multicolumn{3}{|c|}{ P-value } & \multirow{2}{*}{ SA (\%) } & \multirow{2}{*}{ SR (\%) } & \multirow{2}{*}{ ME } & \multirow{2}{*}{ RMSE } \\
\hline & & & a & $\mathrm{B}$ & $\mathrm{c}$ & & & & \\
\hline \multicolumn{10}{|c|}{ Pola tanam I: agroforestry kayu bawang + kopi } \\
\hline \multirow[t]{2}{*}{ S-1 } & OLS & 84,3 & ** & ** & * & 3,37 & 18,22 & 3,064 & 21,862 \\
\hline & WLS & 87,5 & ** & ** & $\operatorname{tn}$ & $-4,19$ & 19,94 & $-3,804$ & 19,770 \\
\hline \multirow[t]{2}{*}{ S-2 } & OLS & 85,5 & $* *$ & ** & ** & 3,30 & 16,98 & 3,001 & 21,457 \\
\hline & WLS & 88,0 & ** & ** & $\operatorname{tn}$ & $-4,50$ & 19,19 & $-4,090$ & 19,181 \\
\hline \multirow[t]{2}{*}{ W-1 } & OLS & 89,6 & tn & $* *$ & $* *$ & 1,47 & 15,12 & 1,334 & 17,374 \\
\hline & WLS & 92,5 & tn & $* *$ & $* *$ & $-0,79$ & 15,66 & $-0,714$ & 17,585 \\
\hline \multirow[t]{2}{*}{ W-2 } & OLS & 70,9 & $*$ & $* *$ & $*$ & 13,16 & 24,75 & 11,961 & 37,789 \\
\hline & WLS & 53,9 & $* *$ & $* *$ & tn & $-13,86$ & 30,49 & $-12,593$ & 28,940 \\
\hline \multirow[t]{2}{*}{ W-3 } & OLS & 69,9 & $* *$ & $* *$ & tn & 0,03 & 27,46 & 0,030 & 25,738 \\
\hline & WLS & 65,3 & $* *$ & $* *$ & tn & 7,04 & 23,82 & 6,394 & 28,298 \\
\hline \multicolumn{10}{|c|}{ Pola tanam II: agroforestry multi jenis } \\
\hline \multirow[t]{2}{*}{ S-1 } & OLS & 87,4 & ** & $* *$ & ** & 1,73 & 14,04 & 1,270 & 11,188 \\
\hline & WLS & 89,9 & $* *$ & $* *$ & ** & $-1,04$ & 14,10 & $-0,765$ & 10,859 \\
\hline \multirow[t]{2}{*}{$\mathrm{S}-2$} & OLS & 84,2 & $* *$ & $* *$ & * & 1,90 & 16,10 & 1,394 & 12,253 \\
\hline & WLS & 87,5 & $* *$ & $* *$ & ** & $-1,52$ & 16,17 & $-1,110$ & 12,208 \\
\hline \multirow[t]{2}{*}{ W-1 } & OLS & 92,6 & tn & $* *$ & ** & 0,53 & 10,54 & 0,388 & 8,660 \\
\hline & WLS & 94,7 & tn & $* *$ & ** & 1,75 & 10,56 & 1,280 & 8,484 \\
\hline \multirow[t]{2}{*}{$\mathrm{W}-2$} & OLS & 81,8 & $* *$ & $* *$ & tn & 4,44 & 19,49 & 3,253 & 14,771 \\
\hline & WLS & 69,5 & $* *$ & $* *$ & tn & $-1,19$ & 18,74 & $-0,870$ & 14,646 \\
\hline \multirow[t]{2}{*}{ W-3 } & OLS & 77,7 & $* *$ & $* *$ & tn & 0,04 & 21,70 & 0,029 & 14,274 \\
\hline & WLS & 89,4 & $* *$ & $* *$ & tn & $-5,55$ & 20,43 & $-4,065$ & 14,942 \\
\hline
\end{tabular}

Keterangan : $\mathrm{R}^{2}=$ koefisien determinasi, $\mathrm{SA}=$ simpangan agregat, $\mathrm{SR}=$ simpangan rata-rata, $\mathrm{ME}=$ bias, $\mathrm{RMSE}=$ akar rata-rata kuadrat simpangan, $\operatorname{tn}=$ tidak nyata $(\mathrm{p}>0,05) \quad *=$ nyata $(\mathrm{p}<0,05), * *=$ sangat nyata $(\mathrm{p}<0,01)$

\section{Proyeksi Pertumbuhan Tegakan pada setiap Pola Tanam}

Model pertumbuhan diameter tegakan terbaik pada pola tanam I adalah $\mathrm{D}=44,710 \mathrm{~A}^{0,44807} \mathrm{~N}$ 0,28443 dan pada pola tanam II: $\operatorname{Ln} D=2,644-1,290 / \mathrm{A}+$ 111,37/N. Setelah memasukkan nilai umur $1-12$ tahun dan kerapatan tegakan 150, 700, dan 1250 pohon per hektar maka akan diperoleh kurva pertumbuhan diameter tegakan kedua pola tanam pada tingkat kerapatan yang berbeda (Gambar 1). Kurva tersebut menunjukkan bahwa pertumbuhan diameter tegakan pada pola tanam kayu bawang + kopi lebih baik dibandingkan dengan pola tanam multi jenis. Hal ini terlihat dari kecenderungan pertumbuhan kayu bawang pada pola tanam agroforestry multi jenis yang semakin berumur semakin meningkat, sedangkan pada pola tanam agroforestry multijenis cenderung tetap.

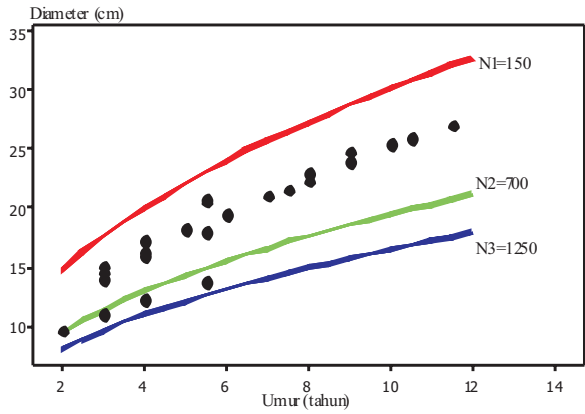

(a)

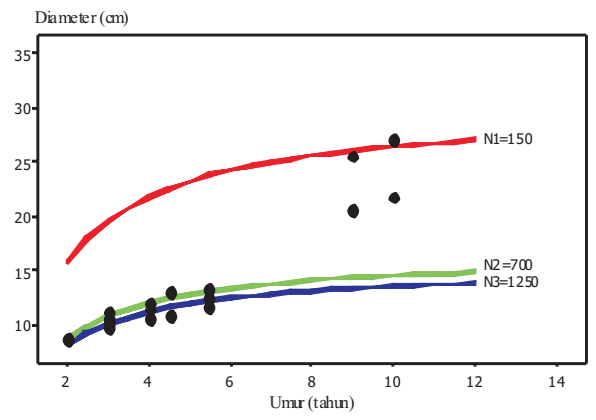

(b)

Keterangan (Remarks): . = data pengamatan (observational data)

- = proyeksi berdasarkan model (projections based on the model)

Gambar (Figure) 1. Kurva pertumbuhan diameter tegakan pada pola agroforestry kayu bawang + kopi (a) dan multi jenis (b) (Stand diametre growth curve of kayu bawang + coffee and multi species agroforestry planting pattern) 


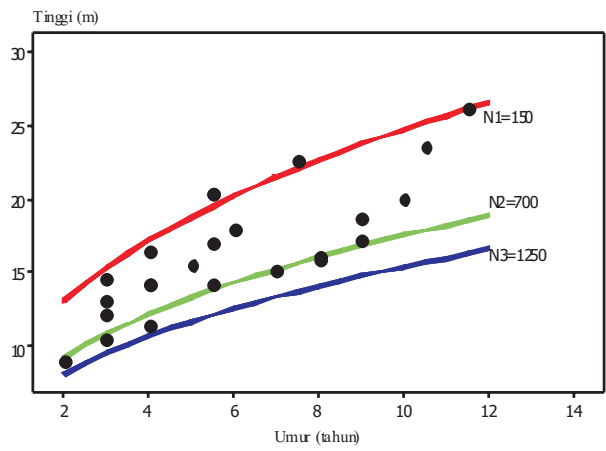

(a)

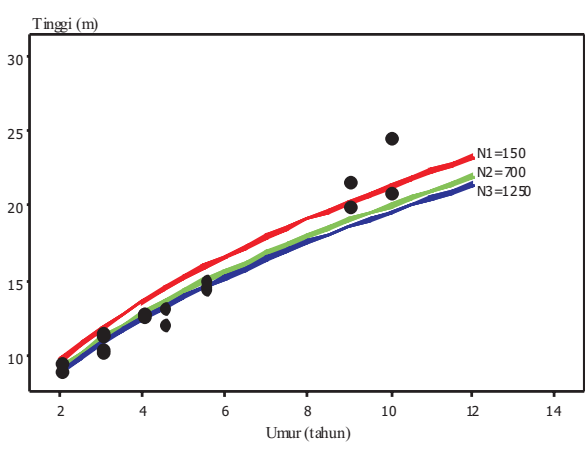

(b)

Keterangan (Remarks): . = data pengamatan (observational data), $-=$ proyeksi berdasarkan model (projections based on the model)

Gambar(Figure)2. Kurva pertumbuhan tinggi tegakan pada pola agroforestry kayu bawang + kopi (a) dan multi jenis (b) (Stand height growth curve of kayu bawang + coffee and multispecies agroforestry planting pattern)

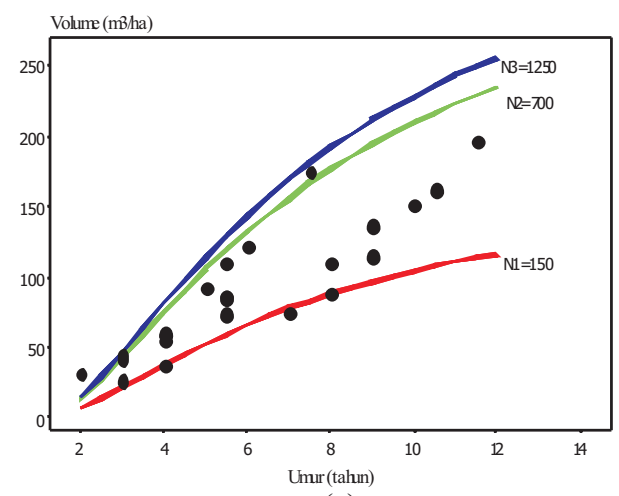

(a)

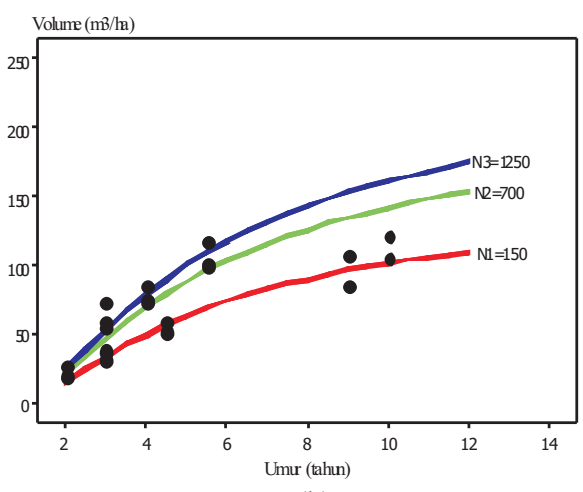

(b)

Keterangan (Remarks): . = data pengamatan (observational data),

- = proyeksi berdasarkan model (projections based on the model)

Gambar(Figure) 3. Kurva pertumbuhan volume tegakan pada pola agroforestry kayu bawang + kopi (a) dan multi jenis (b) (Stand volume growth curve of kayu bawang + coffee and multispecies agroforestry planting pattern)

Berbeda halnya dengan pertumbuhan diameter, pertumbuhan tinggi tegakan pada kedua pola tanam mempunyai model yang sama yaitu model $\mathrm{W}-1$, artinya pertumbuhan tinggi pada kedua pola tanam menunjukkan pola pertumbuhan yang eksponensial dengan nilai eksponen antara 0 dan 1 untuk variabel umur $(\mathrm{A})$ dan antara 0 dan -1 untuk variabel kerapatan tegakan $(\mathrm{N})$. Proyeksi pertumbuhan tinggi tegakan pada kedua pola tanam dapat diperoleh dengan memasukkan nilai umur 1-12 tahun pada model $\mathrm{W}-1$, yaitu $\mathrm{H}=30,411 \mathrm{~A}^{0,39637} \mathrm{~N}^{-0,22306}$ untuk pola tanam agroforestry kayu bawang + kopi dan $\mathrm{H}=8,435 \mathrm{~A}^{0,48002} \mathrm{~N}^{-0,03989}$ untuk pola agroforestry multi jenis (Gambar 2).
Model pertumbuhan volume terbaik pada pola tanam kayu bawang + kopi adalah model S2 , artinya pertumbuhan volume tegakan menunjukkan pola yang logaritmatik terhadap nilai-nilai variabel umur (A) dan kerapatan tegakan $(\mathrm{N})$. Model terbaik pada pola agroforestry multijenis ditunjukkan oleh model S-1, yaitu pertumbuhan yang logaritmatik terhadap umur (A) tetapi eksponensial terhadap kerapatan tegakan $(\mathrm{N})$. Pada pola agroforestry kayu bawang + kopi, model pertumbuhan volume adalah $\mathrm{Ln} V=6,224$ - 6,889/A - 133,85/N dan pada pola agroforestry multijenis dinyatakan oleh model Ln V = 4,001 4,761/A + 0,2187 $\ln \mathrm{N}$. 


\section{B. Pembahasan}

\section{Model Pertumbuhan Tegakan pada Setiap Pola Tanam}

Model pertumbuhan dimensi tegakan kayu bawang berbeda pada masing-masing pola tanam. Kehadiran berbagai jenis tanaman sela pada pola tanam agroforestry multi jenis memberikan pengaruh yang berbeda pada pertumbuhan tegakan kayu bawang dibandingkan kehadiran satu jenis tanaman sela (kopi) pada pola tanam agroforestry kayu bawang + kopi. Ada pula kecenderungan penanaman yang tidak teratur dan persaingan yang lebih keras antara kayu bawang dengan jenis kayu-kayuan lainnya pada pola tanam agroforestry multi jenis, sehingga pertumbuhan kayu bawang kurang baik.

Hasil penelitian menunjukkan bahwa analisis regresi dengan menggunakan metode OLS dan WLS pada model-model yang diujikan memberikan nilai parameter yang relatif sama pada semua variabel pertumbuhan tegakan. Demikian pula nilai-nilai uji statistik $\mathrm{R}^{2}, \mathrm{SA}, \mathrm{SR}$, ME, dan RMSE tidak menunjukkan perbedaan yang nyata. Hal ini berarti bahwa model yang dihasilkan dengan menggunakan analisis regresi dengan metode OLS memberikan akurasi dan ketepatan pendugaan pertumbuhan hampir sama dengan metode WLS. Dengan demikian data serial yang diperoleh dari hasil pengukuran PUP secara berseri dan data cross sectional yang diperoleh dari hasil pengukuran PUP dengan berbagai umur dapat digunakan secara bersamasama dalam menyusun model pertumbuhan tegakan kayu bawang.

Metode regresi OLS merupakan metode yang selama ini digunakan dalam penyusunan model-model pertumbuhan pada hutan tanaman. Metode ini telah digunakan dalam penyusunan model pertumbuhan Sungkai (Peronema canescens Jack.) di Riau (Darwo, 1997), Eucalyptus deglupta di Sulawesi Selatan dan Kalimantan Timur (Harbagung, 1991ª 1996), Eucalyptus urophylla di Jawa Timur (Harbagung, 1991 b), Eucalyptus urograndis di Sumatera Utara (Mindawati et al., 2010), Kayu Titi (Gmelina arborea) di Sumatera Utara (Aswandi dan Ali, 2005), Jati (Tectona grandis) di Jawa (Suharlan et al., 1972), dan Acacia mangium di Jambi dan Kalimantan Selatan (Harbagung, 2004 $4^{\mathrm{a}}, 2004^{\mathrm{b}}$ ).

Secara umum metode regresi OLS dapat digunakan dan memberikan hasil yang tidak berbias, jika data yang digunakan dalam penyusunan model adalah kombinasi data serial dan cross sectional. Berbeda halnya jika seluruh data yang digunakan adalah data serial, maka metode regresi yang digunakan adalah metode regresi terboboti (WLS) (Gujarati, 1978; Draper and Smith, 1992). Oleh karena itu dalam penyusunan model pertumbuhan untuk jenis-jenis tanaman kehutanan yang menggunakan kombinasi data serial dan cross sectional, maka baik metode regresi OLS maupun WLS, keduanya dapat digunakan dan memberikan hasil pendugaan dengan akurasi yang sama.

\section{Proyeksi Pertumbuhan Tegakan pada Setiap Pola Tanam}

Kecenderungan pertumbuhan tegakan kayu bawang pada kedua pola tanam dapat terlihat dari bentuk kurva yang terbentuk setelah dilakukan proyeksi pertumbuhan berdasarkan umur dan kerapatan tegakan pada model terbaik yang diperoleh. Kurva pertumbuhan diameter (Gambar 1), menunjukkan bahwa pertumbuhan diameter tegakan pada pola tanam kayu bawang + kopi lebih baik dibandingkan dengan pola tanam agroforestry multi jenis. Kurva pertumbuhan diameter pada pola tanam agroforestry multijenis terlihat yang telah mulai mendatar pada umur lima tahun sedangkan kurva pola tanam kayu bawang + kopi masih cenderung naik. Artinya bahwa pada umur tersebut pertumbuhan kayu bawang pada pola tanam agroforestry multijenis telah mengalami stagnasi sehingga harus dipanen atau dilakukan penjarangan untuk memberikan ruang tumbuh yang lebih besar.

Gambar 1 juga menunjukkan bahwa semakin tinggi tingkat kerapatan, pertumbuhan diameter akan semakin menurun pada kedua pola tanam. Kerapatan merupakan salah satu faktor yang mempengaruhi pertumbuhan tegakan. Kerapatan menggambarkan tingkat pemanfaatan sumber daya pada suatu tapak (Clutter et al., 1983), oleh karena itu bagaimana memanfaatkan potensi suatu tapak seoptimal mungkin sesuai dengan tujuan pengelolaan merupakan strategi penting dalam pengelolaan hutan tanaman termasuk hutan rakyat. Kurva hubungan kerapatan dengan diameter (Gambar 1) dapat dijadikan sebagai tolok ukur kerapatan tegakan pada masing-masing pola tanam. Misalnya jika diinginkan tegakan dengan diameter rata-rata di atas $30 \mathrm{~cm}$ pada umur 12 tahun maka kerapatan tegakan maksimal pada kedua pola tanam tidak melebihi 150 individu/hektar.

Kehadiran jenis tanaman sela pada pengelolaan hutan rakyat akan mempengaruhi 
pengaturan kerapatan tegakan. Tingkat kerapatan tegakan yang lebih rendah akan dibutuhkan untuk memberi ruang tumbuh, bagi tegakan itu sendiri maupun pada tanaman sela. Jenis tanaman sela itu sendiri akan mempengaruhi bagaimana pengaturan tersebut dilakukan. Tanaman sela seperti kopi (pola tanam agroforstry kayu bawang + kopi) tentu membutuhkan lebih sedikit ruang tumbuh dan memberikan tingkat persaingan yang lebih rendah terhadap tanaman pokok dibandingkan dengan jenis karet, jengkol dan kayu manis pada pola tanam agroforestry multi jenis.

Kurva pertumbuhan volume tegakan sebagaimana terlihat pada Gambar 3 menunjukkan bahwa pada pola agroforestry kayu bawang + kopi terjadi pertumbuhan tegakan yang lebih baik. Hingga umur 12 tahun pada pola tanam tersebut, volume tegakan dapat mencapai 250 $\mathrm{m}^{3} /$ hektar pada kerapatan 1250 pohon/hektar, sedangkan pada pola tanam agroforestry multi jenis hanya mencapai kurang dari $200 \mathrm{~m}^{3} /$ hektar.

Kurva pertumbuhan volume pada Gambar 3 juga menunjukkan bahwa pada kedua pola tanam, pertumbuhan volume tegakan akan semakin tinggi dengan semakin tingginya tingkat kerapatan, tetapi peningkatan volume yang dicapai dari bertambahnya kerapatan dari 150 pohon/hektar menjadi 700 pohon/hektar jauh lebih besar dibanding dengan apabila kerapatan meningkat dari 700 pohon/hektar menjadi 1250 pohon per hektar.

Apabila hal tersebut dihubungkan dengan kurva pertumbuhan diameter, dapat diartikan bahwa, pada tingkat kerapatan tegakan yang lebih tinggi pertumbuhan individu pohon akan semakin menurun tetapi total pertumbuhan per satuan luas akan meningkat. Akan terjadi sebaliknya, apabila tingkat kerapatan yang lebih rendah, total pertumbuhan per satuan luas akan menurun, namun demikian pertumbuhan individu tegakan akan meningkat sehingga kemungkinan dapat menghasilkan kayu yang lebih berharga (Gambar 1 dan 3). Pengaruh kerapatan pada pertumbuhan volume per hektar tergantung pada batas diameter ekonomis. Apabila kayu berukuran diameter besar mempunyai nilai ekonomi per satuan volume lebih tinggi, maka kerapatan yang lebih rendah akan menjadi pilihan sekalipun menghasilkan volume per hektar yang lebih sedikit (Davis et al., 2001).

\section{Riap Tegakan dan Penentuan Daur Optimal}

Perpotongan kurva CAI dan MAI pada pola tanam kayu bawang + kopi (Gambar 6a) terjadi pada saat umur tanaman (A) 7 tahun, hal ini berarti bahwa daur optimum kayu bawang dicapai pada umur 7 tahun. Pada umur ini diameter tegakan dengan kerapatan 150,700, dan 1250 pohon/hektar masing-masing baru mencapai 25,$71 ; 16,59$; dan $14,07 \mathrm{~cm}$, sehingga diperlukan pengaturan kerapatan sesuai dengan tujuan pengusahaan. Misalnya untuk kebutuhan kayu pertukangan yang membutuhkan diameter yang lebih dari $25 \mathrm{~cm}$, kerapatan yang sesuai adalah $\leq 150$ pohon per hektar dan untuk mencapai kondisi nilai kerapatan tersebut dapat dilakukan dengan mengatur jarak tanam pada saat penanaman, atau dengan penjarangan, sehingga pada umur 7 tahun kerapatan yang diperlukan dapat terpenuhi.

Pada tanam agroforestry multi jenis (Gambar 6b), daur optimum adalah 5 tahun, dan pada umur ini diameter baru mencapai 23,14; 12,78; dan $11,90 \mathrm{~cm}$ pada kerapatan berturutturut 150,700 , dan 1.250 pohon per hektar. Dalam hal ini, untuk memenuhi kebutuhan kayu dengan diameter $\geq 25 \mathrm{~cm}$ diperlukan kerapatan $<150$ pohon per hektar atau daur yang lebih besar.
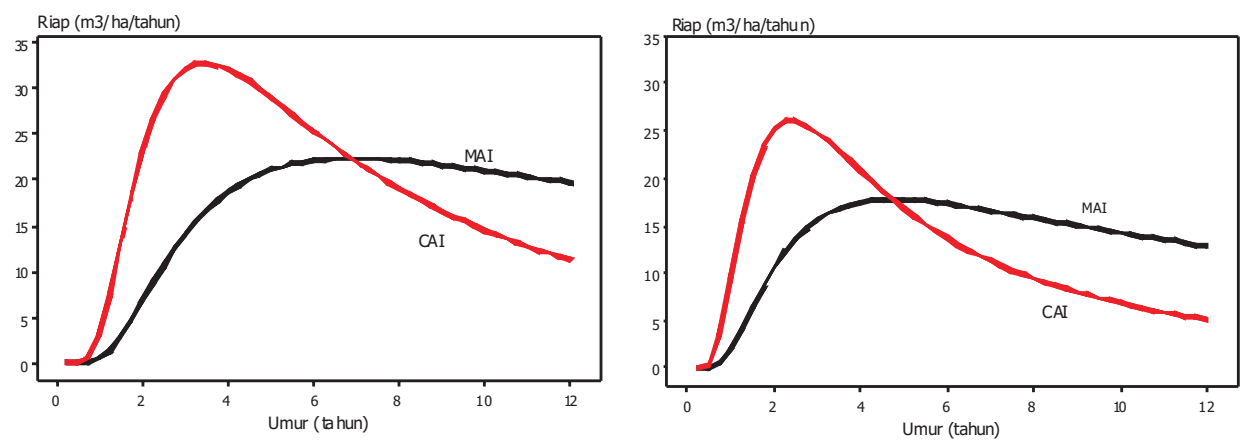

Gambar(Figure) 4. Kurva CAI dan MAI pada pola agroforestry kayu bawang + kopi (a) dan multi jenis (b) (CAI and MAI curve of kayu bawang + coffee (a) and multispecies agroforestry planting pattern) 


\section{KESIMPULAN}

1. Model pertumbuhan tegakan kayu bawang berbeda pada pola tanam yang berbeda. Secara berturut-turut, model pertumbuhan untuk variabel diameter, tinggi, dan volume tegakan kayu bawang adalah $\mathrm{D}=44,710$ $\mathrm{A}^{0,44807} \mathrm{~N}^{-0,28443}\left(\mathrm{R}^{2}=98,0 \%\right), \mathrm{H}=30,411 \mathrm{~A}^{0,39637}$ $\mathrm{N}^{-0,22306}\left(\mathrm{R}^{2}=79,3 \%\right)$, dan Ln $\mathrm{V}=6,224$ $6,889 / \mathrm{A}$ - $133,85 / \mathrm{N}\left(\mathrm{R}^{2}=87,5 \%\right)$ pada pola tanam kayu bawang + kopi, sedangkan pada pola tanam agroforestry multijenis adalah $\mathrm{Ln}$ $\mathrm{D}=2,644-1,290 / \mathrm{A}+111,37 / \mathrm{N}\left(\mathrm{R}^{2}=93,8 \%\right)$, $\mathrm{H}=8,435 \mathrm{~A}^{0,48802} \mathrm{~N}^{-0,03989}\left(\mathrm{R}^{2}=95,0 \%\right)$, dan $\mathrm{Ln}$ $\mathrm{V}=4,001-4,761 / \mathrm{A}+0,219 \ln \mathrm{N}\left(\mathrm{R}^{2}=89,9 \%\right)$.

2. Kerapatan tegakan berkorelasi negatif dengan variabel tinggi dan diameter, berkorelasi positif dengan variabel luas bidang dasar dan volume/ha pada kedua pola tanam, tetapi berkorelasi rendah dengan variabel peninggi tegakan.

3. Daur volume kayu bawang di provinsi Bengkulu, untuk pola tanam kayu bawang + kopi adalah 7 tahun dan pola agroforestry multi jenis adalah 5 tahun.

4. Metode regresi OLS (Ordinary Least Square) dapat digunakan untuk menduga model pertumbuhan tegakan dengan menggunakan kombinasi data serial dan cross sectional secara efisien.

\section{DAFTAR PUSTAKA}

Alder, D. 1980. Forest Volume Estimation and Yield Prediction. FAO. Rome.

Aswandi dan C. Ali. 2005. Model Pertumbuhan dan Hasil Hutan Tanaman Gmelina arborea Menggunakan Petak Ukur Temporer di Sumatera Utara. Jurnal Penelitian Hutan dan Konservasi Alam Vol. II No. 4. Bogor (349-360).

Chatterjee, S. and B. Price. 1938. Regression Analysis by Example. John Wiley \& Sons Inc. New York.

Clutter, J.L., J.C. Fortson., L.V. Pienar., G.H. Brister, and R.L. Bailey, 1983. Timber Management: A Quantitative Approach. John Wiley \& Sons Inc. New York.

Darwo, 1997. Model Pertumbuhan Sungkai (Peronema canescens Jack.) Sampai Umur 6 Tahun di HPH PT Wana Nugraha Bima Lestari Propinsi Riau. Bulletin
Penelitian Kehutanan Vol. 12 No. 4. (315259). Pematang Siantar, Sumatera Utara.

Davis, L.S., K.N. Johnson, P.S. Bettinger, and T.E. Howard, 2001. Forest Management, To Sustain Ecological, Economic, and Sosial Values. Forth Edision. MC GrawHill Book Co. New York.

Dinas Kehutanan Provinsi Bengkulu. 2003. Budidaya Tanaman Kayu Bawang. Dinas Kehutanan Provinsi Bengkulu. Bengkulu.

Draper, N. and H. Smith. 1992. Analisis Regresi Terapan. Bambang Sumantri, penerjemah. Gramedia Pustaka Utama. Terjemahan dari: Applied Regression Analysis. Jakarta.

Gujarati, D. 1978. Ekonometrika Dasar. Sumarno Zain, penerjemah. Penerbit Erlangga. Terjemahan dari: Elementary Econometrics. Jakarta.

Harbagung, 1991 a . Model Pertumbuhan Diameter dan Tinggi Tegakan Hutan Tanaman Eucalyptus deglupta BL. di Borisalo Sulawesi Selatan. Buletin Penelitian Hutan No. 536 (1-16). Bogor.

, 1991 ${ }^{\mathrm{b}}$. Model Pertumbuhan Diameter dan Tinggi Tegakan Hutan Tanaman Eucalyptus urophylla ST. Blake di Daerah Pujon Jawa Timur. Bulletin Penelitian Hutan No. 545 (11-28). Bogor.

, 1996. Model Pertumbuhan Diameter dan Tinggi Tanaman Eucalyptus deglupta BL. di Benakat Sumatera Selatan dan Kenangan Kalimantan Timur. Bulletin Penelitian Hutan No. 599 (15-31). Bogor.

, 2004 ${ }^{\mathrm{a}}$. Model Hasil Tegakan Hutan Tanaman Acacia mangium Wild. di Daerah Semaras Pulau Laut Kalimantan Selatan. Bulletin Penelitian Hutan No. 644 (11-30). Bogor.

2004 . Model Hasil Tegakan Hutan Tanaman Acacia mangium Wild. di Kecamatan Tungkal Ulu Kabupaten Tanjung Jabung Barat Jambi, Sumatera. Bulletin Penelitian Hutan No. 645 (1-23). Bogor.

Huang, S., Y. Yang, and Y. Wang. 2003. A Critical Look at Procedures for Validating Growth and Yield Models. Di dalam: Amaro A., D. Reed, and P. Soares. Modelling Forest Systems. CABI Publishing. London. 
Husch, B. 1963. Forest Mensuration and Statistic. The Ronald Press Company. New York.

Johnson, R.A. and G.K. Bhattacharyya. 1992. Statistic: Principle and Methods. John Wiley \& Sons Inc. New York.

Mindawati, N., A. Indrawan, I. Mansur. dan O. Rusdiana. 2010. Kajian Pertumbuhan Tegakan Hybrid Eucalyptus urograndis di Sumatera Utara. Jurnal Penelitian Hutan Tanaman Vol. 7 No. 1. Bogor.
Widodo, P. 1989. Model Pertumbuhan Hasil Tegakan Hutan Tanaman Seumur Pinus merkusii Jungh et de vriese. Disertasi. Fakultas Pasca Sarjana Institut Pertanian Bogor. Bogor. Tidak diterbitkan.

Wiroatmodjo, P. 1984. Model Perhitungan Pertumbuhan dan Hasil Kayu Bulat Tanaman Pinus merkusii di Jawa (Disertasi) Sekolah Pasca Sarjana Institut Pertanian Bogor. Bogor.Tidak diterbitkan.

Van Laar, A. and A. Akca, 1997. Forest Mensuration. Cuvillier Verlag. Gottingen. 